\begin{tabular}{|l|l|}
\hline \multicolumn{1}{|c|}{ Позитивні сторони застосування } & \multicolumn{1}{|c|}{ Негативні сторони застосування } \\
інтернет-технологій & \multicolumn{1}{|c|}{ інтет-технологій }
\end{tabular}

Незважаючи на недоліки використання інтернет-технологій, все одно позитивні сторони переважають. Метою вчителя, викладача $\epsilon$ навчити раціонально застосовувати інтернет-технології в навчальному процесі, при цьому обов'язково ознайомити 3 негативними сторонами застосування інтернет-технологій.

Слід зазначити, що нині не завжди використовуються можливості інтернеттехнологій, навіть учителями інформатики. Отже, необхідно оновлювати зміст вищої освіти на грунті застосування сучасних інтернет-технологій.

\title{
Література
}

1. Дущенко О. С. Інтернет-технології в професійному становленні майбутніх вчителів інформатики у вищому навчальному закладі / О. С. Дущенко // Матеріали XII Всеукраїнської конференції студентів і молодих науковців «Інформатика, інформаційні системи та технології». - Одеса, 3 квітня 2015 р. - С. 50-52. 2. Іванова О. В. Використання Інтернетресурсів в освітніх цілях (на основі аналізу закордонного досвіду)/ О.В.Іванова [Електронний ресурс] // «Библиотека в школе».- Нижній Новгород. - Режим доступу: http://www.gpntb.ru/win/inter-events/crimea2001/tom/sem1/Doc31.HTML (30.05.15). - Назва 3 екрана. 3. Кривонос О. М. Склад основних компонентів інформаційно-комунікаційних компетентностей вчителя інформатики / О.М.Кривонос [Електронний ресурс] // Вісник Житомирського державного університету. - Випуск 1 (73). Педагогічні науки, 2014. - С. 118 123. - Режим доступу: http://eprints.zu. edu.ua/11186/1/23.pdf (30.05.15). - Назва $з$ екрана. 4. Овчаров С. Актуальні проблеми професійної підготовки учителів інформатики / С. Овчаров [Електронний ресурс] // Педагогічні науки: [збірник наукових праць]. - 2011.C. 73-77. - Режим доступу: http://dspace.pnpu.edu.ua/ bitstream/ 123456789/904/1/Ovcharov.pdf (30.05.15). - Назва 3 екрана. 5. GFK-Ukraine. Прес-релізи «Вже половина українців користуються інтернетом; дві третини 3 них - в соціальних мережах» [Електронний pecypc]. - Режим доступу: http://www.gfk.com/ua/news-and-events/press-room/press-releases/ Pages/internet-use.aspx (30.05.15). - Назва з екрана.

УДК 37.013 .74

Наталія Жданова

\section{СТАНДАРТИЗАЦІЯ ІНШОМОВНОЇ ПІДГОТОВКИ ЕКОНОМІСТІВ У СИСТЕМІ ВИЩОЇ ОСВІТИ УКРАЇНИ}

Жданова Н. С. Стандартизація іншомовної підготовки економістів у системі вищої освіти України.

У статті розглядається питання подолання проблем визначення змісту іншомовної 
освіти в умовах мобільності, потреби уніфікації вимог і порівнюваності рівня іншомовної підготовки, а також урахування особистісних відмінностей студентів (рівень підготовки, кількість занять, оцінки та експертиза критеріїв). Стандартизація іншомовної підготовки студентів економічних спеціальностей може буде досягнутою через інтеграцію фахового змісту у викладання іноземної мови та використання міждисциплінарних зв'язків.

Ключові слова: освіта економістів, курикулум, міждисциплінарні зв'язки.

Жданова Н. С. Стандартизация иноязычной подготовки экономистов в системе высшего образования в Украине.

В статье рассматривается вопрос разрешения проблемы содержания иноязычного образования в условиях мобильности, необходимости унификации требований и соотнесенности уровня иноязычной подготовки, а также учета личностных особенностей студентов (уровень подготовки, количество занятий, оценка и экспертиза критериев). Стандартизация иноязычной подготовки студентов экономических специальностей осуществится на основе интеграции содержания профессионального и языкового образования и использования междисциплинарных связей.

Ключевые слова: образование экономистов, куррикулум, междисциплинарные связи.

Zhdanova N. S. The standardization of foreign languages training of students majoring in economics at institutions of higher education in Ukraine.

The article deals with the question of solving the problem of the content in foreign languages training in response to mobility, the necessity of standartization of the requirements, the relation of foreign languages training levels as well as the consideration of students' personality (entrance level of students, number of lessons, evaluation and examination criteria). The standardization of foreign languages training of students majoring in economics will be achieved through the content integration of professional and foreign language education as well as interdisciplinary integration.

Key words: economist's education, curriculum, interdisciplinary links.

Останнім часом питання стандартизації змісту освіти і визначення рамкових умов навчання фахових і супровідних дисциплін стали одним із актуальних напрямів досліджень. Прагнення України до входження до загальноєвропейського освітнього простору поставило перед науковцями, практиками і працівниками освітніх установ питання про приведення вітчизняної системи освіти, організаційних, методичних засад i змісту навчання у відповідність європейським вимогам.

Іншомовна підготовка $€$ одним із складників змісту освіти фахівців немовних спеціальностей. Однією з вимог, які висуваються до іншомовної підготовки по завершенню курсу навчання у вищій школі, є досягнення рівня В2-C1. Випускник вищої школи має розуміти фахові тексти іноземною мовою, здійснювати комунікацію на побутовому i професійному рівні, узагальнювати фахову інформацію рідною мовою і формулювати висновки іноземною. Досягнення таких результатів можливе лише за умови інтеграції фахового змісту і змісту іншомовного навчання. Тому проблема є актуальною і потребує вивчення.

Мета статmі - дослідити можливості раціонального включення фахового змісту у навчальний процес на заняттях з іноземної мови.

У вищих навчальних закладах України іноземна мова є обов'язковою для вивчення 
дисципліною в межах бакалавріату. Для майбутніх фахівців незалежно від їх спеціалізації, особливо тоді, коли це стосується менеджерів, економістів і співробітників різних галузей, орієнтованих на співробітництво із закордонними підприємствами, іноземна мова $€$ інструментом порозуміння й запорукою успішної діяльності на міжнародному ринку, знання мови дозволяють безперешкодно вирішувати проблеми, не вдаючись до послуг перекладача. Нині зростає кількість зацікавлених у практиці за кордоном, студенти виявляють інтерес до навчання в магістратурі в європейських університетах. Ця тенденція до академічної мобільності студентів береться до уваги і підтримується Міністерством освіти і науки України.

Пропозиції вивчення іноземної мови фахового спрямування на економічних факультетах у вищих навчальних закладах країни відрізняються i терміном вивчення, i змістом навчання. Термін вивчення коливається від 2 до 10 семестрів, кількість годин, відведених на іноземну мову як супровідну дисципліну, становить від 2 до 6 годин на тиждень.

Ділова іноземна мова може викладатися як єдина іноземна або як друга, кількість годин на тиждень може становити від 10 до 25 годин на курс, хоча останнім часом спостерігається стала тенденція до збільшення мінімальної кількості годин до 18-25. Слід також відзначити, що кожен університет і кафедри розробляють власний курикулум. Така ситуація позначається на вихідному рівні знань випускників, які мають різний рівень мовної підготовки і почасти обмежені навички фахового спілкування. За таких умов відсутні підстави до порівняння результатів навчання, а порівнюваність освітніх здобутків є однією 3 вимог мобільності студентів.

Як варіант виходу із ситуації, що склалася, пропонується розроблення курикулуму 3 ділової німецької мови на основі розробленої у 2006 р. й актуалізованої у 2014 р. «Рамкової програми 3 німецької мови професійного спілкування». Ключової метою іншомовного навчання у вищій школі згідно Рамковою програмою $є$ «розвиток діяльнісної комунікативної іншомовної компетенції як у повсякденних, загальних ділових, так і у фахових ситуаціях» [1, c. 10]. Це досягається за рахунок: усвідомлення студентом відносин між власною й іноземною культурами; формування навичок та вмінь автономного навчання; розвиток $\mathrm{i}$ активізація міжфахового мислення; формування власної відповідальності за результати навчання шляхом організації навчального процесу з викладачем й іншими студентами [1, c. 10].

Модель формування професійно орієнтованої міжкультурної комунікативної компетенції представлена на Рис. 1.

Мета навчання передбачає розвиток професійно орієнтованої міжкультурної комунікативно компетенції, яка $є$ складним утворенням, що формується в результаті взаємодії іншомовної комунікативної, фахової, соціокультурної, методичної і навчальної компетенцій. Щодо змісту навчання іноземної мови професійного спілкування економістів, то слід звернути увагу на те, що загальна іншомовна комунікація, як і професійно орієнтована, відбувається в умовах конкретної ситуації, певного соціального контексту. Тому курикулум має охоплювати всі галузі життя (приватну, офіційну, професійну, освітню), які $є$ релевантними до майбутньої професійної діяльності, й формувати зміст навчання 3 урахуванням міждисциплінарних зв’язків у межах конкретної спеціалізації. 


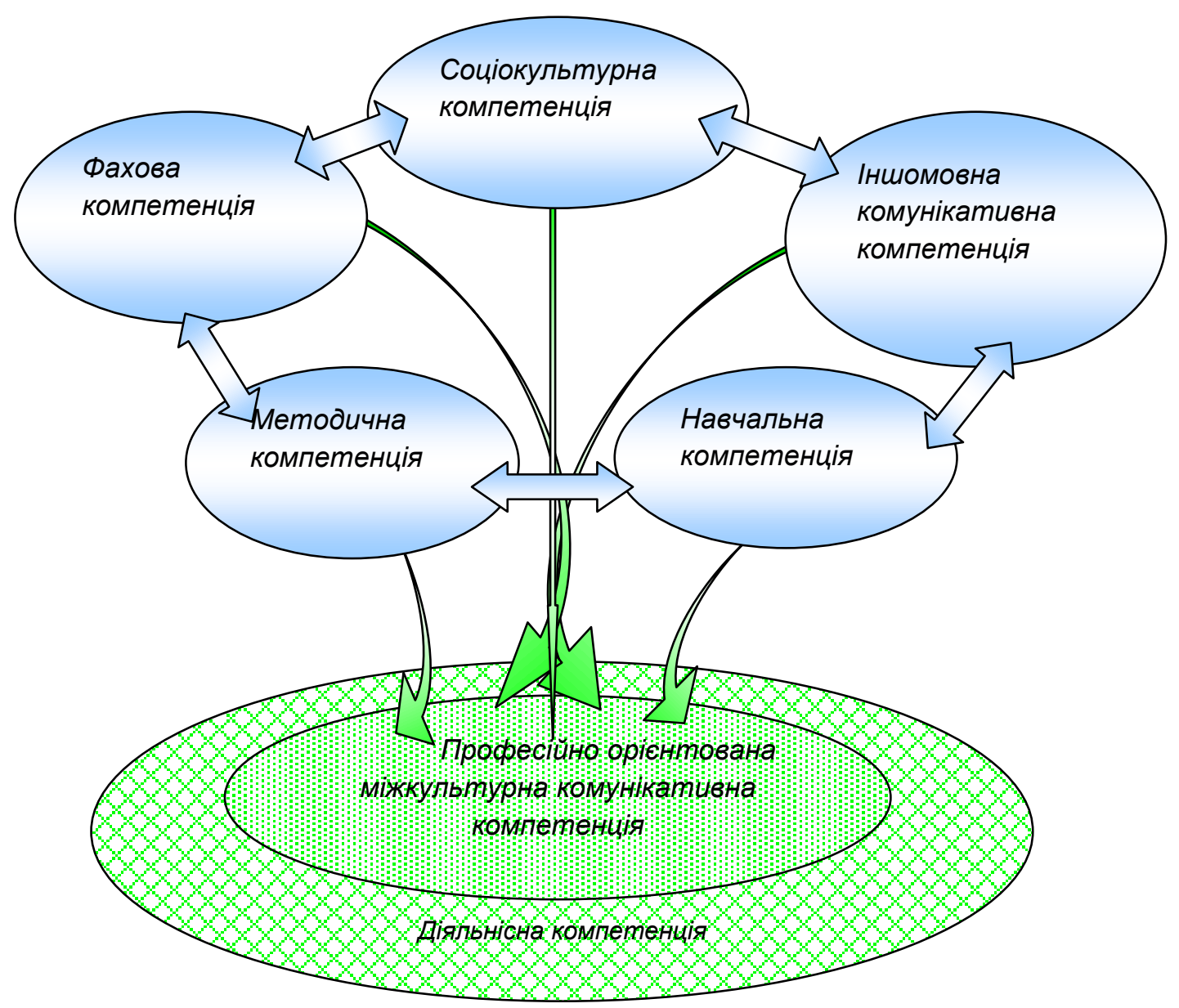

Рис. 1. Модель формування професійно орієнтованої міжкультурної комунікативної компетенції [1, с. 10]

Вибір тем для іншомовного навчання економістів має відбуватися на основі аналізу навчального плану й враховувати фаховий зміст навчання на певному етапі економічної освіти. Навчальний план базової економічної освіти на різних спеціальностях є приблизно однаковим і лише з 5-6 семестрів розпочинається спеціалізація. Це дозволяє включати до розгляду в курсі іноземної мови ті теми, які вже вивчалися в межах фахової підготовки, спиратися на наявні фахові знання і залучати їх до процесу вивчення іноземної мови, розглядати фаховий зміст у контексті «чужої» культури. Наведемо деякі приклади (Таблиця 1) [1].

Таблиияя 1.

Інтеграція фахового змісту у процес іншомовного навчання

\begin{tabular}{|c|c|l|}
\hline Етап & Міждисциплінарні зв'язки & Тематичні блоки іншомовної підготовки \\
\hline Базовий курс & Політекономія & Освіта в Україні й за кордоном (система \\
& Економічна теорія & вищої освіти, студентське життя, \\
& Мікроекономіка & можливості проходження практики); \\
& Україна та німецькомовні країни \\
& (географія, економіка, політичний \\
& устрій); \\
& Економічні системи (планова економіка, \\
& ринкова економіка тощо); \\
& Економіка України, економічні партнери \\
& України; \\
\hline
\end{tabular}




\begin{tabular}{|c|c|c|}
\hline Етап & Міждисциплінарні зв'язки & Тематичні блоки іншомовної підготовки \\
\hline & & $\begin{array}{l}\text { Ділова комунікащія } \quad \text { (співбесіда, } \\
\text { документи для працевлаштування) }\end{array}$ \\
\hline Спеціалізація & $\begin{array}{c}\text { Економіка підприємства } \\
\text { Державне управління } \\
\text { економічною сферою } \\
\text { Зовнішньоекономічна } \\
\text { діяльність }\end{array}$ & $\begin{array}{l}\text { Менеджмент (завдання, діяльність, } \\
\text { функції менеджера) } \\
\text { Німецькомовні країни у світовій } \\
\text { економіці, співробітництво з Украӥною; } \\
\text { Національні й міжнародні підприємства } \\
\text { йорганізації; } \\
\text { Банкові системи, валюти; } \\
\text { Бюджет, податки. }\end{array}$ \\
\hline
\end{tabular}

Наведені в таблиці теми мають рекомендаційний характер і можуть варіюватися залежно від профілю університету, спеціалізації та навчальних можливостей студентів. Доцільно орієнтуватися на фаховий зміст вже з початку навчання в університеті, тобто 3 першого семестру. Водночас, слід звернути увагу на те, що результативним навчальний процес на початковому етапі з іноземної мови фахового спрямування буде лише за умови, якщо фаховий зміст складатиме лише третину від загальної кількості годин.

Отже, пропонований курикулум для економістів розробляється на основі «Рамкової програми 3 німецької мови професійного спілкування», що певною мірою сприяє стандартизації іншомовної підготовки майбутніх економістів. Курикулум з ділової німецької мови описує рамкові умови викладання німецької мови для економістів, за яких навчання іноземної мови відбувається 3 використанням міждисциплінарних зв'язків, із залученням фахових знань економістів та 3 опорою на вже відомий фаховий зміст навчання згідно 3 навчальним планом як на рівні базової економічної освіти, так і на рівні спеціалізації. Такий курикулум може доповнюватися залежно від потреб, але слугуватиме основою для розроблення навчальних програм і надасть змогу уніфікувати підходи до визначення рівня знань студентів-економістів.

\section{Література}

1. Амеліна С. М. Рамкова програма 3 німецької мови для професійного спілкування для вищих навчальних закладів України / С. М. Амеліна, В. А. Гаманюк та ін. - Київ : Ленвіт, 2014. - 136 с. 2. Жданова Н. С. Зміст і структура навчально-методичного комплексу 3 німецької мови для майбутніх менеджерів : дис. ... канд. пед. наук : 13.00.02/ Наталія Сергіївна Жданова. - Київ, 2008. - 344 с.

\section{ОНОВЛЕННЯ ЗМІСТУ ПРОФЕСІЙНОЇ ОСВІТИ І НАВЧАННЯ: СУЧАСНІ ТЕНДЕНЦІЇ Й НАПРЯМИ}

Кантур О. В. Оновлення змісту професійної освіти і навчання: сучасні тенденції й напрями.

У статті розкриваються основи, обгрунтовується актуалізація процесу стандартизації професійної освіти. Аналізуються етапи розробки освітніх стандартів нового покоління на прикладі підготовки працівників туристичної сфери. Характеризується зміст розробленого державного стандарту професійно-технічної освіти на основі компетенцій для робітничої професії.

Ключові слова: модернізація освітньої системи, зміст професійної освіти, 